\title{
The potential of, and threat to, the transfer of ecological knowledge in urban areas: the case of community-based woodland management in Tokyo, Japan
}

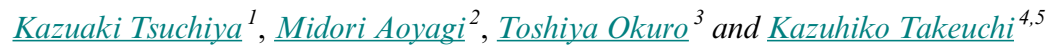

\begin{abstract}
Urban dwellers often have little knowledge of local ecosystems, but community groups that actively manage local ecosystems can acquire a rich ecological knowledge. Understanding the knowledge transfer process within community groups contributes to the continuous improvement of urban ecosystem management. In this paper, we address three main questions: (1) How is ecological knowledge acquisition linked to boundary and intra-group interactions? (2) Does holding knowledge mean the involvement in actual management activities? (3) Does the aging of community group members threaten the continuity of activities? We selected satoyama woodlands (seminatural woodlands) in peri-urban Tokyo, Japan as a study site. We used a mixed method approach that combined a qualitative interview with a quantitative questionnaire. We found that boundary interactions were particularly important at the start of an urban ecological management process, to obtain basic knowledge relating to management activities. Intra-group interaction contributed to knowledge transfer after the starting period. We found that participants possessing considerable ecological knowledge do not necessarily participate in management activities. Findings also indicated that the aging of group members in groups established for more than 10 years was an area of concern for the continuity of group activities. New members did not necessarily solve this aging issue. We conclude that further measures and actions are needed to ensure long-term knowledge transfer among the participants of community groups in urban ecosystem management.
\end{abstract}

Key Words: local ecological knowledge; mixed method; satoyama; urban ecology; woodland management

\section{INTRODUCTION}

As the global population continues to concentrate in and around cities (UN 2011), it is increasingly important to conserve urban green spaces for their biodiversity and ecosystem services (Grimm et al. 2008, Pickett et al. 2011). Global, national, and local organizations around the world have initiated conservation activities for the enhancement of the biodiversity and ecosystem services of green spaces in and around their cities (Secretariat of the Convention on Biological Diversity 2012). It is necessary to consider the significant impact of human activities when conserving urban green spaces (Dow 2000, Andersson 2006, Luck et al. 2009). Urban ecosystem management often involves multiple interacting actors, including local governmental authorities and community groups. Many local governmental authorities in urban areas undertake woodland management activities in protected areas and other urban green spaces (Tsuchiya et al. 2013). Here, the term woodland management refers to direct impacts on woodland vegetation, such as cutting and planting. However, urban ecosystem management by local government is often limited because management in protected areas is costly, and most governments have limited budgets (Colding et al. 2006). Those employed to manage public parks may not have sufficient ecological knowledge, and do not understand how to maintain a park's ecological characteristics (Andersson et al. 2007). Local community groups, who are the users of the land and who can manage the land individually or in a cooperative manner, are recognized as playing an important role in the comanagement of urban ecosystems (Barthel et al. 2005, Bendt et al. 2013). The management activities undertaken by these groups are often volunteer-based and they operate as nongovernmental organizations, nonprofit organizations, and other groups sharing a common interest, such as biological conservation (Ernstson et al. 2008, Nielsen and Möller 2008).

Members of these local community groups need to acquire knowledge relating to ecosystem management. In urban woodland management, knowledge includes: understanding the characteristics of tree species, knowing the appropriate trees to cut, and familiarity with the use of wood products. Urban residents, who generally do not have experience in professional forestry and related works, often lack such ecological knowledge (McDaniel and Alley 2005, Martin et al. 2013). Worldwide urbanization results in fewer people having extensive interactions with nature (Pilgrim et al. 2008). Thus, members of local community groups need to acquire ecological knowledge to conduct appropriate management techniques. Local ecological/ environmental knowledge(Olsson and Folke 2001, McDaniel and Alley 2005, Ballard and Huntsinger 2006), is considered key to successful urban ecosystem management (Yil-Pelkonen and Kohl 2005, Bendt et al. 2013). Knowledge is often acquired though local management practices and differs from conventional scientific knowledge (Ballard et al. 2008). Outdoor activities, such as those undertaken by local community groups, can augment the ecological knowledge of urban citizens through interactions with nature (McDaniel and Alley 2005, Martin et al. 2013). Local community groups can contribute to maintaining biodiversity and can provide ecosystem services in urban areas based on their ecological knowledge (Andersson et al. 2007).

Ecological knowledge is not static (Olsson et al. 2004), and can be improved or diminished depending on the endeavors of community groups. It is widely accepted that the dynamic learning process (Olsson et al. 2004), sometimes called social learning

${ }^{1}$ Faculty of Life and Environmental Sciences, University of Tsukuba, ${ }^{2}$ Center for Social and Environmental Systems Research, National Institute for Environmental Studies, ${ }^{3}$ Department of Ecosystem Studies, Graduate School of Agricultural and Life Sciences, The University of Tokyo,

${ }^{4}$ Integrated Research System for Sustainability Science, The University of Tokyo, ${ }^{5}$ United Nations University 
(Reed et al. 2010) when it involves a group, can improve a manager's ecological knowledge. Although there have been extensive studies on ecological knowledge in traditional systems (Berkes and Folke 1998, Cetinkaya 2009), urban community groups are seldom surveyed from an ecological knowledge viewpoint. Previous studies in urban areas point out the importance of boundary interactions with other actors, and communication within groups (intra-group interaction) as a means of knowledge acquisition and transfer (Bendt et al. 2013), but these have not been widely tested. In this context the term boundary interactions includes social interactions between a community group and other local actors, including municipality officials, farmers, and other community groups. Ecological knowledge acquired by urban dwellers through newspapers and other sources (Martin et al. 2013) may not lead to management activities. Community groups and their participants only learn whether the knowledge is reliable or not when it is implemented in actual management practices. By practically applying it, they understand how certain management activities result in different ecological outcomes. This is an example of learning-by-doing, and it can foster management flexibility. We note that long-term transfer of acquired ecological knowledge in urban areas is not ensured because urban community group activities are often dependent on voluntary participation (Yokohari and Bolthouse 2011a). Acquired ecological knowledge will not be retained if it is not transferred among community members (Oku 2010). This lack of knowledge transfer may lead to poor management of urban biodiversity and ecosystem services. This potential nontransfer of knowledge is not fully addressed in previous research. Thus, there is an urgent need to understand the processes of knowledge acquisition and transfer among urban community groups.

In this study, we examine the knowledge acquisition and transfer process of a local community group managing satoyama woodland (seminatural woodland) in peri-urban Tokyo. We discuss the following questions: (1) How are ecological knowledge acquisition and transfer linked with boundary and intra-group interactions? Through this we explore how groups and individuals acquire ecological knowledge; (2) Does holding knowledge equate to actual involvement in management activities? We discuss the relationship between knowledge and experience in urban settings; (3) Does the aging of community group members threaten continuity of activities? We try to ensure the long-term transfer of ecological knowledge among community group members. We discuss the issues surrounding, and offer solutions for, continuous improvement of ecological knowledge among community groups in urban woodland management.

\section{STUDY SITE}

We selected the northern part of the Tama Hills, located on the western periphery of the Tokyo metropolitan area in Japan, as a case study site (Fig. 1). The area is located approximately $30 \mathrm{~km}$ from central Tokyo, and consists of low mountains and valleys. The hills gradually increase in elevation from east to west, ranging from 80 to $220 \mathrm{~m}$ above sea level (Matsui et al. 1990, Tsunekawa and Bessho 2003). In this area, traditional land uses were adapted to suit the local landscape, rice paddies and crops could be found in the valleys, and satoyama coppice woodlands on the surrounding slopes (Ichikawa et al. 2006). This landscape lasted until the middle of the 20th century (Tsunekawa and Bessho
2003). The traditional satoyama woodland is dominated by coppices that were managed as a source of raw material for charcoal for rural residents during Japan's predevelopment era (Takeuchi 2003). Woodlands were also managed by collecting fallen branches and leaves and clearing the undergrowth, with the harvested products being used as fuel and compost (Ichikawa et al. 2006). Edible plants, mushrooms, and timber trees found in the woodlands were also used by rural residents (Kameyama 1996, Cetinkaya 2009).

Fig. 1. Map of surveyed community groups and satoyama woodland in the northern Tama Hills area of Tokyo, Japan.

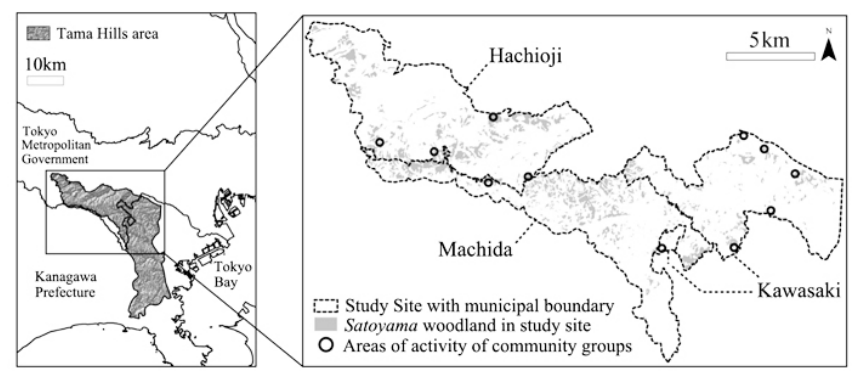

Large areas of woodland disappeared as a result of large-scale urban development during the late 20th century (Ichikawa et al. 2006). Not all woodlands are conserved as a result of formal urban planning, but those that have survived provide biodiversity and ecosystem services (Yokohari et al. 1994, Kobori and Primack 2003). The number of residential developments has decreased and active management of the remaining coppice woodlands, rather than passive land management, i.e., purchasing land to set it aside, has become a crucial policy issue (Yokohari and Bolthouse 2011a). Active management includes creating and executing management plans to achieve a desired goal such as enhanced biodiversity. The biggest problem facing the management of satoyama woodlands is their abandonment by private landowners. Most of these woodlands were abandoned when they lost their economic value as sources of fertilizer, charcoal, food, and timber (Takeuchi 2003). This abandonment resulted in changes in the woodland structure and subsequent losses of plant biodiversity (Iida and Nakashizuka 1995, Koyanagi et al. 2012), historical scenery (Takeuchi 2003), and traditional ecological knowledge relating to the practices that had sustained these woodlands (Cetinkaya 2009). The local government has tried to conserve woodlands by purchasing land from landowners (Tsuchiya and Takeuchi 2010), but the management of such areas can be poor (Tsuchiya et al. 2013). Previous studies report that the abandonment caused a change in the woodland structure of the urbanized Tama Hills (Fujimura 1994). The coppice woodlands, which were composed mainly of Quercus acutissima, Quercus serrata, and Castanea crenata lost their economic value, and hence management largely ceased. The vegetation structure gradually changed from open woodlands to dense forests. The change threatened the biodiversity, ecosystem services, and ecological knowledge of the area.

Volunteer-based management by local community groups (Fig. 2 ) is recognized as effective in mitigating the degradation of 
satoyama woodland (Kobori and Primack 2003). Community group activities are especially common in peri-urban areas of Tokyo and other megacities in Japan (MEJ 2001). The activities are generally organized by voluntary, frequently retired, community members (Yokohari and Bolthouse 2011b). Activities generally involve 10-30 members managing a small patch of woodland (1-3 hectares) on a weekly or monthly basis (Kuramoto and Nagai 2002, Osawa et al. 2001). Previous research proved that community group management can bring ecologically and socially desirable woodlands (Kobori and Primack 2003). The local government realizes the importance community groups play in the management of abandoned satoyama woodland and supports their activities (Tsuchiya and Takeuchi 2010). Community group activities initially started in the late 1970 s (Kuramoto and Nagai 2002), during a time of extreme urban development and satoyama abandonment (Ichikawa et al. 2006). The number of activities grew significantly, with about one thousand groups being active in the early 2000s (MEJ 2001), and this number increasing throughout that decade (Tsuchiya and Takeuchi 2010). Most community group activities in the study area were in publicly owned lands such as public parks or other conserved areas. It is uncommon for the same area to be managed by more than two groups, and rare for community groups to work on private land. Multiple actors can work within a conserved area, e.g., a municipality in the eastern half and a community group in the western half, but it is not usual for different actors in the same category to share the same management area, e.g., we found no example of joint management by two community groups in the study site.

Fig. 2. Example of community group activity at peri-urban satoyama woodland.

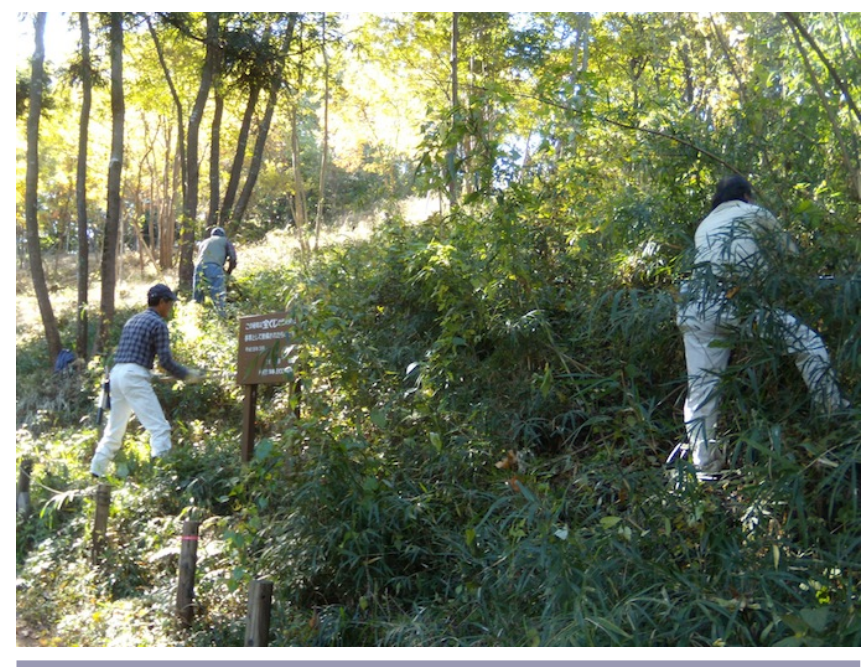

Ecological knowledge in satoyama woodland management includes the choice of trees and grasses to be removed, how to use woody products for charcoal and fertilizers, and how to use mechanical equipment for management activities (Kameyama 1996). Contemporary ecological knowledge differs slightly from the traditional, as public demands relating to satoyama management have changed from needing natural resources, to needing places for nature conservation and recreation (Takeuchi
2003). Although traditional management often includes coppice clearing in 10 to 20 years cycles (Takeuchi 2003), urban community groups do not always clear cut, aiming instead for extensively managed woodland (Kameyama 1996). The ways by which community group members acquire knowledge can vary, from technical workshops organized by municipalities and other organizations (Osawa et al. 2001) to direct knowledge transfer among members (Tatsui and Fujii 2006). The difficulty facing community groups is the continuity of activities (Oku 2010). Because most members join after retirement (Yokohari and Bolthouse 2011a), activities often involve older generations. Community groups recognize the aging problem, and can find it difficult to continue activities (Oku 2010). This emerging threat may also affect knowledge transfer. If older members cannot transfer their knowledge to a younger generation, the acquired knowledge could disappear. Participation of new members may be a solution, but this has not been fully tested. To support the continuity of group activities and transfer of ecological knowledge, it is important to understand the group by focusing on the risk to continuity and the effect of new participants.

\section{METHOD}

We used a mixed method approach (Jick 1979, Johnson et al. 2007) combining a qualitative interview survey with a quantitative questionnaire. We interviewed group leaders and conducted the questionnaire survey with individual participants to gain an understanding of the knowledge transfer and acquisition processes. We also interviewed municipal officials and performed participation observation in each community group's activities to gain further insights into woodland management and related knowledge. This mixed method was previously used in social approaches to ecosystem conservation and management issues (Kumler and Lemos 2008, Sallu et al. 2010, Bottrill et al. 2011). Our mixed method was the QUAL TO QUAN sequential approach (Johnson and Onwuegbuzie 2004) with the qualitative survey being conducted before the quantitative survey, and placing an equal emphasis on both methodologies. The qualitative interview provided crucial information for designing and conducting the questionnaire. The interviews and questionnaires were undertaken from July to December 2010.

Our study area covered three local municipalities: Kawasaki, Machida, and Hachioji (Fig. 1). In the Japanese nationprefecture-municipality governmental hierarchy, Kawasaki belongs to Kanagawa Prefecture, and the other municipalities belong to the Tokyo Metropolitan Government, which operates at the same level as a prefectural government. We selected these municipalities because (1) they have a similar natural and socioeconomic environment because they are adjoining to each other, (2) they have a relatively long history of community groups' activities among Japanese municipalities (Tsuchiya and Takeuchi 2010) thus meet our research objectives, and (3) we could obtain the list of community groups from those municipality offices. We interviewed municipal officials to collect general information and to identify community group areas. We selected this method because most of the group activities were observed in publicly conserved areas (Tsuchiya and Takeuchi 2010). Although they did not know the exact details of community group activities, these officials maintained regular contacts with the stakeholders active in the conserved areas. The officials were key informants about the relationships between conservation measures and the 
Table 1. Name, place, and year of establishment of surveyed community groups.

\begin{tabular}{|c|c|c|c|c|c|}
\hline No. & Group name & Place name & Designated policy type $^{\dagger}$ & $\begin{array}{l}\text { Public land } \\
\text { owner }\end{array}$ & $\begin{array}{l}\text { Activity } \\
\text { since } \\
\end{array}$ \\
\hline 1 & $\begin{array}{l}\text { Utsunuki Ryokuchi } \\
\text { Midorinokai }\end{array}$ & Utsunuki Ryokuchi & Public park / greenery & Hachioji & 1995 \\
\hline 2 & $\begin{array}{l}\text { Zoukibayashiwo } \\
\text { Sodaterukai }\end{array}$ & Ikuta Ryokuchi & Public park / greenery & Kawasaki & 1997 \\
\hline 3 & $\begin{array}{l}\text { Nagaikesatoyama } \\
\text { Kurabu }\end{array}$ & Nagaike Kouen & Public park / greenery & Hachioji & 1998 \\
\hline 4 & Satoyama Borantia & Hayanoseichi Kouen & Public park / greenery & Kawasaki & 1999 \\
\hline 5 & $\begin{array}{l}\text { Ikenosawano Hotaruwo } \\
\text { Mamorukai }\end{array}$ & Tatemachi Ryokuchi Hozen Chiiki & Green Conservation Area & $\begin{array}{l}\text { Tokyo } \\
\text { Metropolitan } \\
\text { Government }\end{array}$ & 2000 \\
\hline 6 & $\begin{array}{l}\text { Mizusawa } \\
\text { Morindonokai }\end{array}$ & Mizusawano Mori & Public park / greenery & Kawasaki & 2001 \\
\hline 7 & $\begin{array}{l}\text { Ozawajoshi } \\
\text { Satoyamanokai }\end{array}$ & $\begin{array}{l}\text { Ozawajoshi Tokubetsu Ryokuchi Hozen } \\
\text { Chiku }\end{array}$ & Green Conservation Area & Kawasaki & 2001 \\
\hline 8 & $\begin{array}{l}\text { Asoutamamino } \\
\text { Morinokai }\end{array}$ & Asoutamami Kenkouno Mori & Public park / greenery & Kawasaki & 2001 \\
\hline 9 & $\begin{array}{l}\text { Kawasaki Shizento } \\
\text { Kyouseinokai }\end{array}$ & $\begin{array}{l}\text { Okauenashikonoki Tokubetsu Ryokuchi } \\
\text { Hozen Chiku }\end{array}$ & Green Conservation Area & Kawasaki & 2005 \\
\hline 10 & Yatoyamanokai & Oyamadairi Kouen & Public park / greenery & $\begin{array}{l}\text { Tokyo } \\
\text { Metropolitan } \\
\text { Government }\end{array}$ & 2006 \\
\hline 11 & Kyuuryouchi Borantia & Naganuma-Hirayamajoshi Kouen & Public park / greenery & $\begin{array}{l}\text { Tokyo } \\
\text { Metropolitan } \\
\text { Government }\end{array}$ & 2007 \\
\hline
\end{tabular}

${ }^{\dagger}$ Public park / greenery is publicly owned urban parks and green areas designated under the Urban Park Act. Green conservation area is the mix of privately and publicly owned green areas designated under the Urban Green Space Conservation Act.

associated management. The interviewees were officials from the Kawasaki, Machida, Hachioji, and Tokyo metropolitan governments, and a total of seven were interviewed. We did not conduct interviews in the Kanagawa Prefectural Government because there was no satoyama woodland managed under the prefecture's conservation measures. This means that the list of community groups of Kanagawa prefecture in our study site could be covered by the information from Kawasaki municipality. Interviews were undertaken in a semistructured style with openended questions, and we asked for a list of groups and about interactions between the officials and the groups. We also collected municipal documents related to group activities.

Twenty-six active groups were identified from the municipality interview and document survey. Among those, 11 groups were contacted directly from the address contained in the documents or from websites. We were not able to reach the other 15 groups with the available information. Table 1 shows the list of contacted groups and Figure 1 shows the distribution of group activities across the study site. All of the groups conducted volunteer-based woodland management in 1-2 hectares sites in public parks or other conserved areas. All of the groups were established after the late 1990s, and the average length of group existence was 11.36 years. Registered group numbers varied from 16 to 250 , and the average numbers of participants for each individual activity was lower than the registered number; it varied from 5 to 30 people in each group (Table 2). We conducted a semistructured interview with open-ended questions with the leaders of each group, to investigate the knowledge acquisition and transfer processes. One or two interviewees were chosen from current or former group leaders of each group. Interview sessions took 60 to 90 minutes. Interviewees were questioned on: why the group was established, management activities conducted in a single year, knowledge acquisition and transfer processes within the group, cooperation with other actors, and concerns about the future continuity of group activities. Interviewees were visited more than once if a single interview was not sufficient. Eighteen interview sessions were carried out in total. The number of ongoing activities per group was identified by continuous work on the following major activities in satoyama woodland management: undergrowth management, tree thinning, composting woody materials (e.g., fallen leaves), mushroom growing, clear cutting/coppice management, and charcoal making. Activities conducted in the past, or undertaken a few times experimentally were not included. We also physically observed the activities of all groups to understand the behavior of and the communication among participants. We also collected information on generational, gendered, and organizational aspects of group activities in participation observation. 
Table 2. Number of group members: registered, average, respondents.

\begin{tabular}{lccc}
\hline \hline No. & $\begin{array}{c}\text { Number of } \\
\text { registered } \\
\text { members }\end{array}$ & $\begin{array}{c}\text { Average } \\
\text { number of } \\
\text { participants } \\
\text { for each } \\
\text { individual } \\
\text { activity }^{\dagger}\end{array}$ & $\begin{array}{c}\text { Number of } \\
\text { respondents to } \\
\text { questionnaire }\end{array}$ \\
\hline 1 & 50 & 15 & 19 \\
2 & 30 & 10 & 8 \\
3 & 250 & 5 & 6 \\
4 & 70 & 30 & 22 \\
5 & 52 & 12 & 9 \\
6 & 90 & 30 & 24 \\
7 & 35 & 10 & 12 \\
8 & 56 & 8 & 16 \\
9 & 105 & 30 & 12 \\
10 & 16 & 10 & 4 \\
11 & 36 & 10 & 13 \\
\hline
\end{tabular}

${ }^{\dagger}$ These numbers were provided by group leaders during interviews.

From our interviews and active group participation we developed a questionnaire on the knowledge and experience of satoyama woodland management. Because most groups do not maintain volunteer personal details we did not conduct a postal questionnaire. We visited each individual group activity and asked each participant to fill out a questionnaire. This approach enabled us to confirm whether the respondents clearly understood the questions and correctly completed the questionnaire. We collected a total of 145 responses from 11 groups. The number of responses covered an almost even spread of regular participants (Table 2). The list of questions included: knowledge about satoyama woodlands, experience in management activities, group participation personal history, and personal details (such as age). For knowledge about satoyama woodlands, we adopted eight major characteristics as variables (Table 3) based on the previous literature about management activities (e.g., Kameyama 1996, Takeuchi 2003) and interviews with the group leaders. For experience in management activities, we asked about physical activities in woodland management, tree/grass selection process before management activities, and the use of woody products. Details of questionnaire procedures and the list of questions are shown in Appendix 1. Table 3 summarizes the questions on knowledge and experience used in the questionnaire.

From the interview and questionnaire data, we conducted: (1) statistical analysis on the quantitative questionnaire data, and (2) combined analysis of the qualitative and quantitative data. For the statistical analysis, we calculated two aggregated values to express different dimensions of ecological knowledge: knowledge values and experience values. Knowledge values were established from the total number of "Yes I know" answers to the eight questions on the general understanding of the traditional and contemporary roles of satoyama woodland. Experience values estimated from the total number of "Yes I have experience" answers to 15 questions on common activities in satoyama woodland. We chose to sum up the number of "Yes" replies (Pilgrim et al. 2008, Martin et al. 2013) because that sum can be much more simply applied in other situations. Although some previous studies used statistical method to provide integrated values for ecological knowledge (e.g., McDaniel and Alley 2005), we did not adopt this method because it may have made interpretation of values more difficult. In addition to the amount of knowledge, we also used the number of experiences because it can represent an important part of knowledge related to management activities (e.g., when and how to cut trees), which may not be represented solely by the amount of knowledge.

We examined explanatory variables that influence these two values by using a generalized linear mixed model (GLMM). GLMM is used in both ecological and social science fields to allow for the random effect of the statistical model (Rasbash and Goldstein 1994, Bolker et al. 2009). We established GLMM statistical models by using knowledge and experience values as response variables. The model was established with a binomial distribution and logit link function. Groups were used to mixed effect in the model because nonquantitatively measured grouplevel variables may affect the values. We used the following variables from the questionnaire result: years participating, participation in other groups (two categories: have and have not), age (three categories: under 50, 60, and 70), sex (two categories: male and female), motivation for joining (five categories: social interactions with other members, interest in the natural environment, interest in agricultural activities, contribution to the local community, and feeling refreshed in both body and mind), and experience in professional forestry, agriculture, or landscaping (two categories: have and have not). Akaike Information Criterion (AIC) scores were used to select the optimal combination of explanatory variables to predict the two values: knowledge and experience. Estimated regression coefficients, standard errors of coefficients, and $\mathrm{z}$ values (Wald statistics) were calculated in the selected models. The analysis was conducted using version 2.11 .0 of the $\mathrm{R}$ statistical software ( $\mathrm{R}$ Development Core Team 2010) and its glmmML analytical package, version 0.82 (Broström and Holmberg 2011).

For the combined analysis of qualitative and quantitative data, we used the years the group was in existence and the number of management activities, both obtained from the interviews. We also used the average participating years obtained from the questionnaires. We analyzed whether these group characteristics affected the knowledge and experience values at a group level. We investigated whether leaders' concerns on group continuity related to the length of group establishment or the average participating years, to measure the effect of aging and the entry of new participants.

\section{RESULTS}

\section{Management activities and knowledge acquisition processes at the community level}

Management activities for each group are summarized in Table 4. Undergrowth management and tree thinning were undertaken by all groups. Fallen leaves collection/composting and mushroom growing were undertaken by approximately half of the surveyed 
Table 3. Questions to individuals on knowledge and experience in woodland management.

\begin{tabular}{|c|c|c|}
\hline $\begin{array}{l}\text { Type of } \\
\text { question }\end{array}$ & Questions & Number of yes respondents $($ total $=107)$ \\
\hline \multicolumn{3}{|c|}{ Ecological knowledge } \\
\hline & \multicolumn{2}{|l|}{$\begin{array}{l}\text { Do you know the following characteristics of } \\
\text { satoyama woodland? }\end{array}$} \\
\hline & Producing fuel and charcoal & 85 \\
\hline & Producing compost from collected fallen leaves & 90 \\
\hline & Collecting edible mushrooms and plants & 60 \\
\hline & Planting and growing mushrooms on logged trees & 79 \\
\hline & Timber use of logged trees & 57 \\
\hline & Creating habitats for animals and plants & 91 \\
\hline & Providing public recreational spaces & 72 \\
\hline & Using as educational spaces for nature and culture & 76 \\
\hline \multicolumn{3}{|c|}{ Management experience } \\
\hline & \multicolumn{2}{|l|}{$\begin{array}{l}\text { Have you ever experienced the following } \\
\text { management activities yourself? }\end{array}$} \\
\hline & Cutting undergrowth with hand sickles & 103 \\
\hline & $\begin{array}{l}\text { Cutting undergrowth with machine (e.g., brush } \\
\text { cutter) }\end{array}$ & 57 \\
\hline & Removing exotic species & 79 \\
\hline & Cutting trees with hand saws & 96 \\
\hline & Cutting trees with machine (e.g., chain saws) & 47 \\
\hline & Pruning tree branches & 69 \\
\hline & Managing shoots from the trunks of coppiced trees & 42 \\
\hline & Planting new trees and establishing seedlings & 80 \\
\hline & Selecting grasses not to be cut (i.e., protected) & 86 \\
\hline & Selecting exotic species to be removed & 81 \\
\hline & Selecting trees not to be cut (i.e., protected) & 81 \\
\hline & $\begin{array}{l}\text { Selecting branches to be retained during pruning and } \\
\text { shoot management }\end{array}$ & 71 \\
\hline & Making fertilizers from collected fallen leaves & 83 \\
\hline & Making charcoal from logged trees & 56 \\
\hline & Planting and growing mushrooms on logged trees & 78 \\
\hline
\end{tabular}

groups (between 5 and 7 of the 11 groups). Coppice clearing and charcoal making, the core elements of traditional satoyama woodland management, were conducted by only 2 of the 11 groups. Groups were less likely to undertake activities that require advanced and complex knowledge. An interview of the two groups conducting clear cutting and charcoal making revealed that they had received lectures on these activities from local farmers. Only one group (No. 9) undertook management activities with other community groups or actors.

Table 4 summarizes the knowledge acquisition processes in the surveyed groups, obtained through interviewing group leaders. $\mathrm{O}$ the 11 groups, 8 exploited the launching of community activities to obtain basic knowledge and techniques on satoyama woodland management from municipality staff, local farmers, or other related actors. Most participants were woodland management novices with little ecological knowledge. Table 4 shows that in most cases (in 9 of the 11 groups) participants who joined the group at a later stage acquired previously learned knowledge through interaction with other group members. These learning processes included knowledge gained from organized lectures and day-to-day communication. In addition, learning by doing processes were observed most clearly in charcoal making in group Nos. 3 and 4. It often fails if one does not correctly control the strength and length of fire with consideration of tree characteristics, and participants learned from the failure about charcoal making processes. Municipal official interviews revealed that some of their organizations arranged both indoor and outdoor classes on satoyama woodland management; however, only one group availed itself of such opportunities after the initial period. The knowledge acquisition process differed during the group launching period and subsequent periods. Boundary interactions with municipalities and other actors were important to acquire management knowledge in the launch stage, although it had little effect in later periods. Intra-group interaction during activities was crucially important to transmit the acquired knowledge to new participants.

\section{Ecological knowledge and management experience at an individual level}

We received 145 responses to individual questionnaires (Table 2). Of those, we analyzed 107 fully completed surveys. The other 38 incomplete surveys did not clearly answer several questions. This may have been because we asked but did not force the respondents 
Table 4. Management activities and learning processes in community groups.

\begin{tabular}{|c|c|c|c|c|c|c|c|c|}
\hline \multirow[b]{2}{*}{ No. } & \multicolumn{2}{|c|}{ Knowledge acquisition process } & \multicolumn{6}{|c|}{ Group management activities } \\
\hline & $\begin{array}{l}\text { Learning in initial stage } \\
\text { of group activity (no. of } \\
\text { people who were part of } \\
\text { the group from the start) }\end{array}$ & $\begin{array}{l}\text { Learning in later stage of } \\
\text { group activity (no. of } \\
\text { people who joined later) }\end{array}$ & $\begin{array}{l}\text { Undergrowth } \\
\text { management }\end{array}$ & $\begin{array}{c}\text { Tree } \\
\text { thinning }\end{array}$ & Composting $^{\dagger}$ & $\begin{array}{l}\text { Mushroom } \\
\text { growing }\end{array}$ & $\begin{array}{c}\text { Clear } \\
\text { cutting }\end{array}$ & $\begin{array}{l}\text { Charcoal } \\
\text { making }\end{array}$ \\
\hline 1 & $\begin{array}{l}\text { Lecture from local } \\
\text { farmers and other } \\
\text { groups (1) }\end{array}$ & $\begin{array}{l}\text { Learning through activities } \\
\text { (13) }\end{array}$ & $\sqrt{ }$ & $\sqrt{ }$ & $\sqrt{ }$ & $\sqrt{ }$ & & \\
\hline 2 & N/A $(0)$ & $\begin{array}{l}\text { Kawasaki Municipality } \\
\text { Staff (4) }\end{array}$ & $\sqrt{ }$ & $\sqrt{ }$ & & & & \\
\hline 3 & $\begin{array}{l}\text { Lecture from public } \\
\text { development company } \\
\text { (2) }\end{array}$ & Workshop within group (3) & $\sqrt{ }$ & $\sqrt{ }$ & $\sqrt{ }$ & $\sqrt{ }$ & $\sqrt{ }$ & $\sqrt{ }$ \\
\hline 4 & Municipality Staff (0) & $\begin{array}{l}\text { Workshop within group } \\
\text { (17) }\end{array}$ & $\sqrt{ }$ & $\sqrt{ }$ & $\sqrt{ }$ & $\sqrt{ }$ & $\sqrt{ }$ & $\sqrt{ }$ \\
\hline 5 & Municipality Staff (1) & $\begin{array}{l}\text { Workshop by Tokyo } \\
\text { Metropolitan Government } \\
\text { (8) }\end{array}$ & $\sqrt{ }$ & $\sqrt{ }$ & & $\sqrt{ }$ & & \\
\hline 6 & Municipality staff (4) & $\begin{array}{l}\text { Workshop within group } \\
\text { (13) }\end{array}$ & $\sqrt{ }$ & $\sqrt{ }$ & $\sqrt{ }$ & & & \\
\hline 7 & $\begin{array}{l}\text { Lecture from local } \\
\text { farmers (1) }\end{array}$ & $\begin{array}{l}\text { Learning through activities } \\
\text { (6) }\end{array}$ & $\sqrt{ }$ & $\sqrt{ }$ & $\sqrt{ }$ & $\sqrt{ }$ & & \\
\hline 8 & Municipality Staff (4) & $\begin{array}{l}\text { Learning through activities } \\
\text { (9) }\end{array}$ & $\sqrt{ }$ & $\sqrt{ }$ & $\sqrt{ }$ & & & \\
\hline 9 & No special lecture (1) & $\begin{array}{l}\text { Learning through activities } \\
\text { (6) }\end{array}$ & $\sqrt{ }$ & $\sqrt{ }$ & $\sqrt{ }$ & & & \\
\hline 10 & No special lecture (1) & $\begin{array}{l}\text { Learning through activities } \\
\text { (9) }\end{array}$ & $\sqrt{ }$ & $\sqrt{ }$ & & & & \\
\hline 11 & Municipality Staff (0) & $\begin{array}{l}\text { Learning through activities } \\
\text { (4) }\end{array}$ & $\sqrt{ }$ & $\sqrt{ }$ & & & & \\
\hline
\end{tabular}

${ }^{\dagger}$ This includes collecting fallen branches and leaves

Coppice management of woodlands dominated by Quercus acutissima, Quercus serrata, and Castanea crenata

to answer all questions to avoid unconsidered responses. More than half (68 out of 107) of the respondents stated that they almost always participated in activities. Age proportion was 53 respondents in their $60 \mathrm{~s}(49.53 \%), 37$ in their $70 \mathrm{~s}(34.58 \%)$, and 17 under 50 (15.89\%). Gender proportion was 87 males $(81.31 \%)$ and 13 females (12.15\%). The majority of participants lived close to the activity areas $(87,81.31 \%)$. Fifteen members $(14.02 \%)$ had been involved in activities since the group establishment, showing that many of the current participants had joined subsequent to the launch period. The mean participation length among respondents was 5.34 years, less than half the mean activity length of groups (11.36 years). The most common reason for joining was an invitation from friends or neighbors (47 responses), followed by information provided by groups or municipalities (38 responses). Interestingly, some participants (63 responses) had joined another group's activities, contradictory to the interview findings, which revealed that most groups did not conduct joint management activities. A low number of individuals (20 responses) had prior experience of forestry, agriculture, or landscaping, which corresponded with the interview findings that many participants were initially beginners in satoyama management activities. Table 3 summarizes the responses to the questions relating to ecological knowledge of and management experience in satoyama woodland. Approximately $70 \%$ of respondents possessed a general level of knowledge, whereas fewer respondents knew about mushroom and edible plant collection (60 responses), and timber uses (57 responses). Compared with ecological knowledge, the responses on experience in management activities varied significantly. Simpler activity types, such as undergrowth cutting by sickles (103 responses), obtained a higher experience rate, whereas complex activities such as charcoal making (56 responses), obtained a lower experience response.

Table 5 shows the aggregated values from both ecological knowledge and management experience questions by all respondents and groups. Mean values for knowledge and experience values at an individual level were $5.70(\max 8)$ and 10.36 ( $\max 15)$, respectively. At an individual level, the correlation between knowledge and experience values was 0.34 . The average of both values varied among the groups; however, they were not statistically related to group activity years, average participating years, and the number of activities conducted by the groups. Mean knowledge values were highest at group No. 3 (6.80) and lowest 
at group No. 6 (4.29). Mean experience values were highest at group No. 5 (13.22) and lowest at group No. 9 (7.86). The correlation between the two values at a group level was only 0.25 . Table 5 also shows the standard deviation of the two values within each group, illustrating the variety of knowledge and experience levels among group participants.

Table 5. Summary of knowledge and experience values.

\begin{tabular}{lccccc}
\hline \hline & \multicolumn{2}{c}{$\begin{array}{c}\text { Ecological } \\
\text { knowledge }\end{array}$} & & \multicolumn{2}{c}{$\begin{array}{c}\text { Management } \\
\text { experience }\end{array}$} \\
\cline { 2 - 3 } \cline { 5 - 6 } & $\begin{array}{l}\text { Mean } \\
\text { value }\end{array}$ & SD & & $\begin{array}{c}\text { Mean } \\
\text { value }\end{array}$ & SD \\
\hline Individual level & 5.70 & 2.42 & & 10.36 & 3.90 \\
Group level & & & & \\
No.1 & 6.00 & 2.17 & 8.43 & 3.64 \\
No.2 & 4.75 & 2.17 & 12.50 & 1.50 \\
No.3 & 6.80 & 1.47 & 11.20 & 2.32 \\
No.4 & 5.71 & 2.72 & 11.47 & 3.11 \\
No.5 & 6.11 & 2.02 & 13.22 & 1.31 \\
No.6 & 4.29 & 2.52 & 10.53 & 3.66 \\
No.7 & 6.29 & 2.66 & 9.43 & 4.03 \\
No.8 & 5.92 & 2.16 & 8.46 & 4.96 \\
No.9 & 4.57 & 2.13 & 7.86 & 4.70 \\
No.10 & 6.60 & 1.80 & 11.30 & 3.16 \\
No.11 & 7.25 & 0.83 & 12.00 & 1.73 \\
\hline
\end{tabular}

Table 6 shows the variables selected through AIC in binomial GLMM, by using the two aggregated values as response variables. The two values were defined by a different combination of variables. The knowledge value was best defined by career length, age, and motivation of participants. The AIC value of this model was 379.5 , and the scale parameter in mixing distribution was 0.58 . The AIC value for full model (with all parameters) was 381.8 . Participants with a greater length of participation and younger participants had better knowledge values. Among the motivation variables, participants with an interest in the natural environment possessed the highest knowledge values, whereas participants with an interest in social interactions with other members gained the lowest knowledge values. The experience value was best defined by career length, participation in other groups, sex, and professional experience. The AIC value of this model was 286.4, and the scale parameter in mixing distribution was 0.46 . The AIC value for full model was 288.2. Participants with a greater length of participation, being male, participating in other groups, and with professional experience had greater experience values. In summary, the members who participated longer had higher knowledge and experience values.

\section{Leaders' concerns on the continuity of group activities}

We combined the interview and questionnaire results to focus on the concern relating to the continuity of group activities (Fig. 3). The average length of participation increased until the groups were in existence for 13 years. This changed as the groups approached the 14-year mark because the groups then experienced a lowering of average participation years. More than half of the surveyed groups (6 groups) had concerns about the continuity of group activities. These groups were in existence for more than 10 years. Two groups (Nos. 4 and 9) experienced aging issues that affected management activities, and had stopped or scaled down a part of activities (e.g., cutting down large trees, undergrowth management at steep area) or reduced the frequency of management activities. The other four groups (Nos. 1, 2, 6, and 8) did not experience obvious aging effects, but the representative was concerned about the continuity of group activities in the near future. These group leaders cited the aging of group members, together with a low number of new participants, as the reasons for their concerns. The remaining five groups (Nos. 3, 5, 7, 10, and 11) did not have concerns about the continuity of group activities.

Fig. 3. Concerns relating to the continuity of group activities. Group activity/average participation years by group.
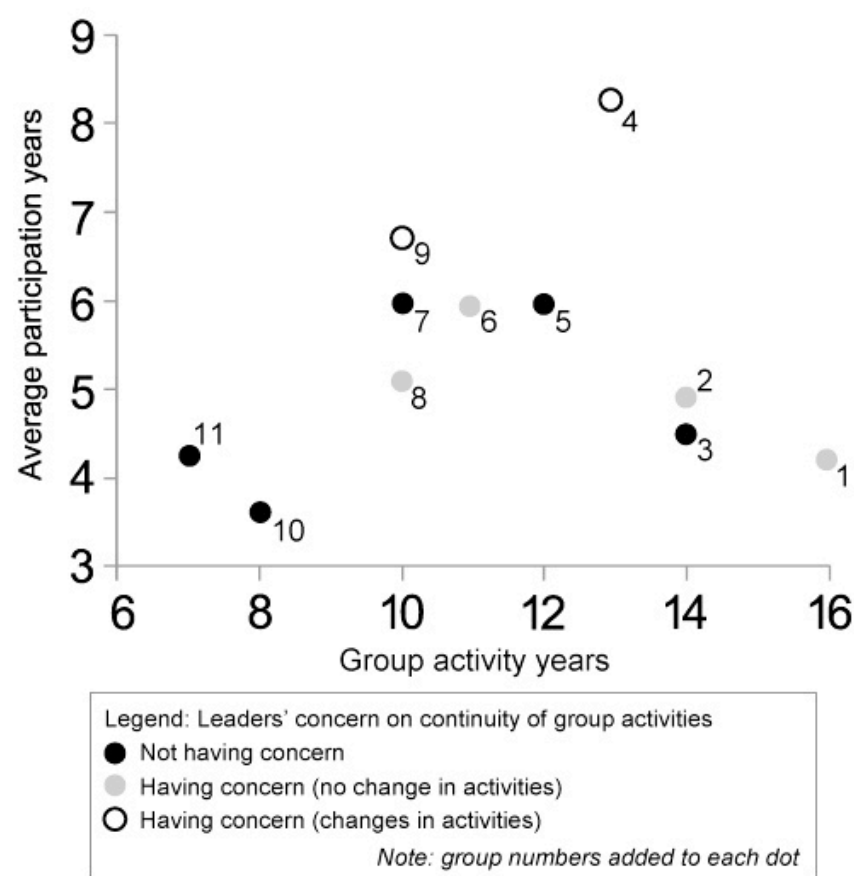

\section{DISCUSSION}

Ecological knowledge acquisitions were affected both by intragroup and boundary interactions

Our statistical model showed that longer participation in community groups contributed to better knowledge and experience levels. This result implied that participation in community group activities led to the acquisition and implementation of ecological knowledge related to satoyama management by urban dwellers. Whereas previous studies pointed out the loss of traditional ecological knowledge related to satoyama management because of the abandonment of traditional management (Cetinkaya 2009, Cetinkaya et al. 2012), our analysis indicated that community group activities can mitigate the loss of ecological knowledge, especially in peri-urban areas. Knowledge acquisition is important in urban areas, where people possess less ecological knowledge than in other areas (McDaniel and Alley 2005, Pilgrim et al. 2008) and have less experience with nature (Miller 2005). Previous studies 
Table 6. General linear mixed model results for knowledge and experience values.

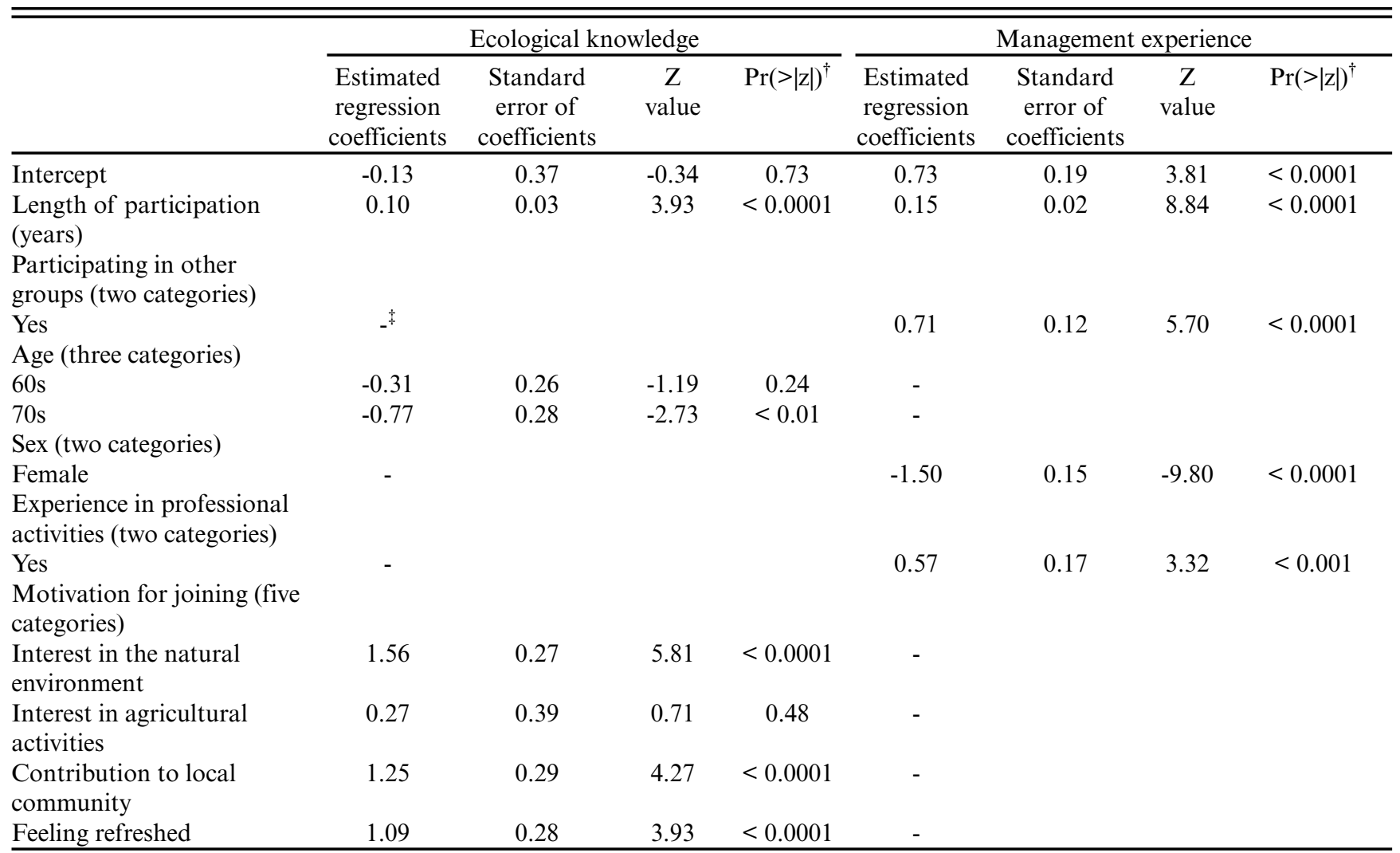

${ }^{\dagger}$ The probability of including zero value of coefficients within Wald confidence interval

All blank (-) areas were not used in the selected model using AIC

hypothesized that community-based activities may provide an opportunity to obtain ecological knowledge in urban areas (Martin et al. 2013, Yli-Pelkonen and Kohl 2005). This hypothesis had not been sufficiently quantitatively tested; our findings have contributed to addressing this gap.

As shown in the interview results (Table 4), interactions between community group members were the main source of knowledge transfer after the initial group start period. The statistical model shows that a longer participation in community group activities contributes to greater ecological knowledge and management experience levels. This supports the interview findings that longer participation may lead to greater interactions with other community group members. Tatsui and Fujii (2006) point out, in their in-depth case study of one community group, that interaction among members within community groups contributes to knowledge transfer related to satoyama woodland management. Our research found that such contributions can be found in both multiple groups and at an individual level. Participant networks may affect ecological knowledge transfer in urban settings (Barthel et al. 2010, Bendt et al. 2013); just as farmers obtain knowledge related to farming activities through local farmers' networks (Isaac et al. 2007). The direction of knowledge transfer in community groups is assumed to be from participants with longer participation to participants with shorter participation (Ballard and Huntsinger 2006). The effect of longer participation also implied that participants kept learning about satoyama woodland management through trying new activities one by one.

The interviews revealed (Table 4) that many of the surveyed groups underwent training workshops provided by other actors on the initial establishment of the group. This implies that boundary interactions with other actors may contribute to the acquisition of ecological knowledge among participants. In Japan, many urban municipalities organize or support satoyama woodland management by providing urban citizens with an opportunity to learn about the ecology, history, and management of satoyama woodland (Osawa et al. 2001). Although these workshops may not always contribute to the establishment of community group activities, our results show that the effects of workshops were common among active community groups. The leaders of interviewed groups reported that the lessons learned in these workshops were implemented by community groups. Bendt et al. (2013), emphasized the importance of boundary interactions in the social learning processes of garden communities in urban areas, and indicated that higher levels of boundary activities increase the learning streams within these 
communities. Our results also showed the importance of boundary interaction in urban woodland management communities and added new findings, highlighting that interaction is especially effective in the early periods of group activities.

Both intra-group and boundary interactions are important sources of knowledge acquisition for community group participants, and the two interactions have different influences in the initial and subsequent periods of community group activities. Although boundary interactions played an important role in the initial stage of group activities, there was no obvious impact in later periods. This corresponded with our interview findings that few groups conduct management activities in conjunction with other actors. In urban ecosystem management, community groups are often fragmented, and have insufficient collaboration with other actors (Borgström et al. 2006, Holt et al. 2012). Thus, the independence of community groups may lead to less interaction with other actors for knowledge acquisition. Despite limited boundary interactions, intra-group interaction contributed to knowledge transfer between old and new group participants. This process can lead to the evolution of the overall group knowledge base from general to specialized. If so, intra-group interaction provides a valuable opportunity to develop and transfer specialized local ecological knowledge (Olsson et al. 2004).

Questionnaire results showed that 63 participants (58.9\%) joined the activities of other groups, and our regression analysis (Table 6) shows that participants who joined another group's activities had higher experience levels. Previous literature on community group activities in satoyama woodland management examines each group individually, rather than looking at involvement in multiple groups. The results on the involvement of individuals in multiple groups were somewhat contradictory, with the grouplevel interview results showing that few groups conduct management activities with other groups. Previous studies have pointed to the fragmentation of community groups in urban ecosystem management (Borgström et al. 2006, Ernstson et al. 2010, Holt et al. 2012); however, we found little evidence of individual-level interactions across groups. Because of their high experience levels, those individuals who join multiple groups may contribute to knowledge transfer between groups as a knowledge transporter. If one group undertakes certain activities, e.g., mushroom production, and another group does not, knowledge transporters who join both groups may transfer knowledge to the second group based on their experiences in the first. Our questionnaire respondents were limited to regular participants, and we did not investigate whether they joined other groups; however, the high levels of knowledge transporters found, and their contribution to knowledge and experience levels, implies that they can play a crucial role in local-scale knowledge transfer.

\section{Individual attributes affecting ecological knowledge and management experience}

As shown in Table 5, multiple individual attributes affect the degree of individual knowledge and experience in satoyama woodland management. This result suggests that individual knowledge and experience levels differ among participants based on their personal attributes. The younger generation (below 50s) had higher knowledge values; however, age was not strongly related to experience values. This suggests that the younger generation has abstract knowledge about satoyama woodland, but not necessarily experience in management activities. This probably derives from the different reasons for joining satoyama management activities between generations. Participants in their $60 \mathrm{~s}$ and 70 s frequently join after retirement, and consider the activity as a hobby (Yokohari and Bolthouse 2011a). Younger participants often join management activities while still working and thus may be highly motivated to learn about environmental and social issues in satoyama woodlands. Among the motivation variables, we found that an interest in the natural environment strongly contributed to the knowledge level, whereas the participant who joined for social reasons had a lower knowledge level. These interests only affected the knowledge value, perhaps because the acquisition of abstract knowledge is more strongly related to these psychological values, whereas involvement in actual group activities may be related to management activities implemented in groups. The differences in experience values between female and male participants imply the different roles they undertake in satoyama management activities. During our participation observation, we found that groups with a large number of participants (Nos. 4 and 9) have subgroups, and female participants tend to contribute indirectly, e.g., preparing tools and meals, but not in hard physical labor, e.g., cutting down large trees. Those with professional experience take initiatives in actual management activities, showing the positive effect that professional experience has on experience values. Previous studies on community-based urban ecosystem management focused on community-level phenomena (e.g., Bendt et al. 2003), but few have investigated ecological knowledge at an individual level and its relationship to personal attributes. Our study attempted to address this gap, and showed that the involvement of many types of people may increase the diversity of ecological knowledge at a local level. This diversity may enhance the interactions between individuals with different knowledge and experience levels.

Table 3 summarizes the response to knowledge and experience questions, showing that knowledge is possessed by a limited number of respondents. Among the knowledge values, questions on mushroom and edible plant collection and timber uses obtained a lower "Yes" response rate than other questions. This knowledge was common among farmers in the Tama Hills area in its predevelopment era (Kameyama 1996), but is not always undertaken in the current community group-based management, as confirmed in the interviews. This is probably because urban society does not depend on food or wood products from the forest for a living. Among the experience values, questions on the complex type of activities, such as charcoal making, obtained a lower "Yes" response rate than other questions. A lower "Yes" response rate for machine-related activities may be related to internal rules within community groups. Group leader interviews revealed that many of the groups had internal rules such as participants needing to undertake machinery workshops organized by municipalities or other organizations. The lower response rate for charcoal making was in line with the interview findings that only two groups included charcoal making in their activities (Table 4). Charcoal making requires large equipment, such as a kiln, and these types of socio-material resources can be important for knowledge acquisition (Bendt et al. 2013). The lower response rate for charcoal making can be explained by the lack of necessary resources in the other groups. 
The correlation between individual-level knowledge and experience values was not strong, implying that knowledge and experience values might represent different types of individual knowledge possessions. The individual-level low correlation was in line with correlations at the group levels, and this implied that the individual-level correlation was somewhat affected by grouplevel factors. However, group-level values were not significantly related to their measured variables including: group activity years, average participation years, and the number of activities undertaken by groups. One possible explanation for this low correlation may come from unmeasured qualitative differences such as objectives, reasons, or interests underlying the participation in satoyama management activities (Kuramoto and Nagai 2002, Tatsui and Fujii 2006). For example, an individual who wants to physically cut a tree may not be interested in the literal knowledge itself.

\section{Threats to knowledge transfer in peri-urban satoyama woodland} The interviews with group leaders revealed that half of the groups had concerns relating to the continuity of group activities (Fig. 3 ), and two groups had eliminated some activities requiring greater physical labor. The loss of large tree cutting activities potentially has a significant impact on biodiversity and ecosystem services (e.g., plant species on forest floor and cultural services) of satoyama woodlands because it was used for coppice for a long time and its ecosystem structure was dependent on the continuous clear cutting (Takeuchi 2003). The growth of tree size after the abandonment of traditional management (Oku 2010) may also make the difficult situation worse in the near future. Group leaders cited the low number of new participants and the subsequent overall average aging of participants as their main concerns. Questionnaire results agreed with this concern about aging because most participants were in their $60 \mathrm{~s}$ or $70 \mathrm{~s}$. Because of their age, it is not easy to participate in activities on a long-term basis. Although our interview found that most of the groups tried to recruit new members through advertising in local newspapers or group's website, these efforts did not clearly contribute to a solution. Figure 3 also shows that the average length of individual participation increased the longer a group was in existence. However, when a group had been in existence for 13-14 years, the average length of participation decreased, probably because of an increase in the rate of new participants joining a group. Group Nos. 5 and 10 were concerned about continuity despite their lower average participation years. Although the ratio of noninitial participants was high among the respondents, those new participants were also mostly in their 60 s or 70 s. Thus, the involvement of new participants might not sufficiently mitigate the concern for the continuity of group activities. Previous studies showed that remote rural areas in Japan experience problems with the transfer of traditional ecological knowledge because the knowledge is often limited to older people (Cetinkaya 2009). Our study showed a similar situation emerging in the growing community-based management activities in urban areas. Thus, for the sustainable transfer of ecological knowledge among urban dwellers, it is crucial to encourage the participation by younger generations in satoyama management activities. For example, a greater communication between urban ecosystem management and environmental education in schools may contribute to the long-term transfer of ecological knowledge among urban dwellers (Krasny and Tidball 2009).
We argue that both desirable and undesirable trends are emerging with the increase in group activity years. A positive outcome is the increased ecological knowledge and management experience gained by participants. The increased average participation years leads to a richer level of ecological knowledge, as well as to concerns about group continuity. A more negative outcome is the threat to knowledge transfer due to participant aging. Recent discussions on the role of social memory in ecosystem management (Barthel et al. 2010, 2013) emphasized the importance of social interaction to facilitate individual knowledge and practical experience. Such theoretical perspective implies that the loss of elder members from community groups may affect the transfer of acquired knowledge by reducing the chances of social interactions. Bendt et al. (2013) mentioned the potential trade-offs between broad-based participation and fostering deeper knowledge in a garden management community in Berlin, Germany. If a group encourages broad participation, it is difficult to deepen the knowledge base; on the other hand, if a group aims to develop deeper knowledge, it is difficult to have broad-based participation. Our results empirically showed that similar trade-offs occurred in the satoyama management community in Tokyo. This issue is especially crucial in urban satoyama woodland, because the age of group participants tends to be limited to older people. Group activities not directly related to woodland management may attract people who are not initially interested in the woodland management activity itself (Bendt et al. 2013), and may thus contribute to ensuring long-term continuity. For example, the use of harvested mushrooms or edible plants in cookery classes or outdoor restaurants may attract people who are interested in healthy food. This idea is supported by the finding that younger generation urban dwellers prefer products from the nearby satoyama areas (Chen and Qiu 2012). We also point out the role knowledge transporters can play in solving continuity issues. Knowledge transporters can bring knowledge from closing groups to newly launched groups, and thus may contribute to sustainable knowledge transfer in a region. To maintain regional ecological knowledge, it is important to consider individual-level knowledge transfers across multiple groups, ensuring the continuity of each group's activities.

There are several limitations to this study. First, our findings from the questionnaire may be limited to regular participants. In addition to this, we only dealt with active groups in this study and were not able to contact the groups that had already stopped their activities. To overcome this, a long-term monitoring of group activities would include regular participants, infrequent participants, retired members, and newly joined participants. Second, our knowledge and experience values were calculated based on self-recognition by respondents. We chose this method because it is easier to answer in an extensive field questionnaire. However, this can lead to personal biases in relation to having or not having the knowledge or experience and cannot clearly integrate qualitative aspects of proficiency in management activities. Including another objective measurement, such as longterm observation of actual management activities, may improve the clarity and objectivity of the measured values. Third, although our results strongly suggest that both intra-group and boundary interactions contribute to knowledge transfers among individuals and groups, we did not measure the relational data among individuals and groups that is used in social network analysis 
(Ernstson et al. 2008, Holt et al. 2012). The future inclusion of social network methodologies is important to understand knowledge transfer processes and the role of knowledge transporters.

\section{CONCLUSIONS}

Our findings can be summarized as follows: (1) Both intra-group and boundary interactions contribute to knowledge transfer in peri-urban community-based satoyama woodland management. Boundary interactions are particularly important in the launch phase to obtain basic knowledge relating to management activities, and intra-group interactions contribute to knowledge transfer and acquisition after the launch phase. (2) Many participants join multiple groups, and those participants generally hold richer management experience. It is assumed that they act as knowledge transporters between multiple groups. (3) Ecological knowledge and management experience are affected by individual attributes, and knowledge and experience values are not necessarily strongly correlated. (4) The aging of group members in groups established for more than 10 years raises concerns relating to the continuity of group activities. Involvement of new participants does not necessarily contribute to solving this aging issue. Based on these findings, we conclude that further measures and actions are needed to ensure the longterm knowledge transfer and acquisition among the participants of community groups in satoyama woodland management. Enhanced cooperation between satoyama management groups and other local organizations will encourage further participation from different generations, and transfer knowledge throughout the generations. Community groups can extend their range of activities to facilitate participation of those who are not interested in management itself.

Responses to this article can be read online at: http://www.ecologyandsociety.org/issues/responses. $\mathrm{php} / 6369$

\begin{abstract}
Acknowledgments:
This research was supported by a Grant-in-Aid for JSPS Fellows (09J06164) from the Japanese Ministry of Education, Culture, Sports, Science and Technology. We thank all the interviewees and questionnaire respondents from community groups in the Tama Hills area and officials in Kawasaki, Machida, Hachioji, and Tokyo metropolitan governments. Dr. Satoru Okubo and Dr. Tomoo Okayasu of the Department of Ecosystem Studies, Graduate School of Agricultural and Life Science, The University of Tokyo, provided valuable comments on earlier versions of the manuscript. We also thank the members of the Laboratory of Landscape Ecology and Planning of The University of Tokyo for their useful comments on and discussion of an earlier analysis of our data and earlier drafts of our paper, and for their support during our research.
\end{abstract}

\section{LITERATURE CITED}

Andersson, E. 2006. Urban landscapes and sustainable cities. Ecology and Society 11(1): 34. [online] URL: http://www. ecologyandsociety.org/vol11/iss1/art34/
Andersson, E., S. Barthel, and K. Ahrné. 2007. Measuring socialecological dynamics behind the generation of ecosystem services. Ecological Applications 17:1267-1278. http://dx.doi.org/10.1890/06-1116.1

Ballard, H., M. E. Fernandez-Gimenez, and V. E. Sturtevant. 2008. Integration of local ecological knowledge and conventional science: a study of seven community-based forestry organizations in the USA. Ecology and Society 13(2): 37. [online] URL: http:// www.ecologyandsociety.org/voll3/iss2/art37/

Ballard, H. L., and L. Huntsinger. 2006. Salal harvester local ecological knowledge, harvest practices and understory management on the Olympic Peninsula, Washington. Human Ecology 34:529-547. http://dx.doi.org/10.1007/s10745-006-9048-7

Barthel, S., J. Colding, T. Elmqvist, and C. Folke. 2005. History and local management of a biodiversity-rich, urban cultural landscape. Ecology and Society 10(2): 10. [online] URL: http:// www.ecologyandsociety.org/vol10/iss2/art10/

Barthel, S., C. Crumley, and U. Svedin. 2013. Bio-cultural refugia - safeguarding diversity of practices for food security and biodiversity. Global Environmental Change 23:1142-1152. http:// dx.doi.org/10.1016/j.gloenvcha.2013.05.001

Barthel, S., C. Folke, and J. Colding. 2010. Social-ecological memory in urban gardens-retaining the capacity for management of ecosystem services. Global Environmental Change 20:255-265. http://dx.doi.org/10.1016/j.gloenvcha.2010.01.001

Bendt, P., S. Barthel, and J. Colding. 2013. Civic greening and environmental learning in public-access community gardens in Berlin. Landscape and Urban Planning 109:18-30. http://dx.doi. org/10.1016/j.landurbplan.2012.10.003

Berkes, F., and C. Folke 1998. Linking social and ecological systems for resilience and sustainability. Pages 1-25 in F. Berkes, C. Folke, and J. Colding, editors. Linking social and ecological systems: management practices and social mechanisms for building resilience. Cambridge University Press, Cambridge, UK.

Bolker, B. M., M. E. Brooks, C. J. Clark, S. W. Geange, J. R. Poulsen, M. H. H. Stevens, and J.-S. S. White. 2009. Generalized linear mixed models: a practical guide for ecology and evolution. Trends in Ecology \& Evolution 24:127-135. http://dx.doi. org/10.1016/j.tree.2008.10.008

Borgström, S. T., T. Elmqvist, P. Angelstam, and C. AlfsenNorodom. 2006. Scale mismatches in management of urban landscapes. Ecology and Society 11(2): 16. [online] URL: http:// www.ecologyandsociety.org/vol11/iss2/art16/

Bottrill, M. C., M. Hockings, and H. P. Possingham. 2011. In pursuit of knowledge: addressing barriers to effective conservation evaluation. Ecology and Society 16(2): 14. [online] URL: http://www.ecologyandsociety.org/vol16/iss2/art14/

Broström, G., and H. Holmberg. 2011. glmmML: Generalized linear models with clustering. $\mathrm{R}$ package version $0.81-8$. $\mathrm{R}$ Foundation for Statistical Computing, Vienna, Austria. [online] URL: http://cran.r-project.org/web/packages/glmmML/index. $\underline{\text { html }}$

Cetinkaya, G. 2009. Challenges for the maintenance of traditional knowledge in the Satoyama and Satoumi ecosystems, Noto Peninsula, Japan. Human Ecology Review 16:27-40. 
Cetinkaya, G., K. Nakamura, A. Kambu, D. Akaishi, and D. Utsunomiya. 2012. Traditional knowledge and landscape management: evaluation and measurement of traditional knowledge on edible wild plants and mushrooms in the satoyama ecosystems in the Noto Peninsula, Japan. Journal of Environmental Planning and Management 55:141-160. http://dx. doi.org/10.1080/09640568.2011.586417

Chen, B., and Z. Qiu. 2012. Consumers' attitudes towards edible wild plants: a case study of Noto Peninsula, Ishikawa Prefecture, Japan. International Journal of Forestry Research 2012:1-16. http://dx.doi.org/10.1155/2012/872413

Colding, J., J. Lundberg, and C. Folke. 2006. Incorporating greenarea user groups in urban ecosystem management. Ambio 35:237-244. http://dx.doi.org/10.1579/05-A-098R.1

Dow, K. 2000. Social dimensions of gradients in urban ecosystems. Urban Ecosystems 4:255-275. http://dx.doi. org/10.1023/A:1015767231137

Ernstson, H., S. Barthel, E. Andersson, and S. T. Borgström. 2010. Scale-crossing brokers and network governance of urban ecosystem services: the case of Stockholm. Ecology and Society 15(4): 28. [online] URL: http://www.ecologyandsociety.org/ vol15/iss4/art28/

Ernstson, H., S. Sörlin, and T. Elmqvist. 2008. Social movements and ecosystem services-the role of social network structure in protecting and managing urban green areas in Stockholm. Ecology and Society 13(2): 39. [online] URL: http://www. ecologyandsociety.org/vol13/iss2/art39/

Fujimura, T. 1994. The changes of secondary forests due to the decline in farm forest type usage of the Tama Hills. Journal of Japanese Institute of Landscape Architects 57:211-216. http://dx. doi.org/10.5632/jila1934.57.5_211

Grimm, N. B., S. H. Faeth, N. E. Golubiewski, C. L. Redman, J. Wu, X. Bai, and J. M. Briggs. 2008. Global change and the ecology of cities. Science 319:756-760. http://dx.doi.org/10.1126/ $\underline{\text { science. } 1150195}$

Holt, A. R., P. Moug, and D. N. Lerner. 2012. The network governance of urban river corridors. Ecology and Society 17(4): 25. [online] URL: http://dx.doi.org/10.5751/ES-05200-170425

Ichikawa, K., N. Okubo, S. Okubo, and K. Takeuchi. 2006. Transition of the satoyama landscape in the urban fringe of the Tokyo metropolitan area from 1880 to 2001. Landscape and Urban Planning 78:398-410. http://dx.doi.org/10.1016/j.landurbplan.2005.12.001

Iida, S., and T. Nakashizuka. 1995. Forest fragmentation and its effect on species diversity in sub-urban coppice forests in Japan. Forest Ecology and Management 73:197-210. http://dx.doi. org/10.1016/0378-1127(94)03484-E

Isaac, M. E., B. H. Erickson, S. J. Quashie-Sam, and V. R. Timmer. 2007. Transfer of knowledge on agroforestry management practices: the structure of farmer advice networks. Ecology and Society 12(2): 32. [online] URL: http://www.ecologyandsociety. org/vol12/iss2/art32/

Jick, T. D. 1979. Mixing qualitative and quantitative methods: triangulation in action. Administrative Science Quarterly 24:602-611. http://dx.doi.org/10.2307/2392366
Johnson, R. B., and A. J. Onwuegbuzie. 2004. Mixed methods research: a research paradigm whose time has come. Educational Researcher 33:14-26. http://dx.doi.org/10.3102/0013189X033007014

Johnson, R. B., A. J. Onwuegbuzie, and L. A. Turner. 2007. Toward a definition of mixed methods research. Journal of Mixed Methods Research 1:112-133. http://dx.doi.org/10.1177/1558689806298224

Kameyama, A., editor. 1996. Zoukibayashi no syokusei kanri [Vegetation management in coppice woodland]. Soft-Science, Tokyo, Japan.

Kobori, H., and R. B. Primack. 2003. Participatory conservation approaches for satoyama, the traditional forest and agricultural landscape of Japan. Ambio 32:307-11.

Koyanagi, T., Y. Kusumoto, S. Yamamoto, and K. Takeuchi. 2012. Potential roles of small and linear habitat fragments in satoyama landscapes for conservation of grassland plant species. Urban Ecosystems 15:893-909. http://dx.doi.org/10.1007/ s11252-012-0253-4

Krasny, M., and K. Tidball. 2009. Community gardens as contexts for science, stewardship, and civic action learning. Cities and the Environment 2:1-18.

Kumler, L. M., and M. C. Lemos. 2008. Managing waters of the Paraíba do Sul river basin, Brazil: a case study in institutional change and social learning. Ecology and Society 13(2): 22. [online] URL: http://www.ecologyandsociety.org/vol13/iss2/art22/

Kuramoto, N., and K. Nagai. 2002. Opinions about the activities and organization of volunteers working for the conservation of the coppice Sakuragaoka park in Tokyo. Journal of Japanese Institution of Landscape Architects 65:455-460. http://dx.doi. org/10.5632/jila.65.455

Luck, G. W., L. T. Smallbone, and R. O'Brien. 2009. Socioeconomics and vegetation change in urban ecosystems: patterns in space and time. Ecosystems 12:604-620. http://dx.doi. org/10.1007/s10021-009-9244-6

Martin, L. E., M. G. Sorice, and U. P. Kreuter. 2013. Understanding and influencing urban residents' knowledge about wildland management in Austin, Texas. Urban Ecosystems 16:33-51. http://dx.doi.org/10.1007/s11252-011-0177-4

Matsui, K., K. Takeuchi, and T. Tamura 1990. Kyuuryouchi-noShizen-Kankyo [Natural environment of hilly areas]. KokinShoin, Tokyo, Japan.

McDaniel, J., and K. D. Alley. 2005. Connecting local environmental knowledge and land use practices: a human ecosystem approach to urbanization in West Georgia. Urban Ecosystems 8:23-38. http://dx.doi.org/10.1007/s11252-005-1417-2

Miller, J. R. 2005. Biodiversity conservation and the extinction of experience. Trends in Ecology \& Evolution 20:430-434. http://dx. doi.org/10.1016/j.tree.2005.05.013

Ministry of Environment, Japan (MEJ). 2001. Nihon-no satochi satoyama no chosa bunseki nit suite [Survey and analysis on Japanese satoyama landscapes]. [online] URL: http://www.env. go.jp/nature/satoyama/chukan.html 
Nielsen, A. B., and F. Möller. 2008. Is coppice a potential for urban forestry? The social perspective. Urban Forestry \& Urban Greening 7:129-138. http://dx.doi.org/10.1016/j.ufug.2008.02.005

Oku, H. 2010. Changing contexts of contemporary satoyama landscapes. Journal of Japanese Institution of Landscape Architects 74:82-85.

Olsson, P., and C. Folke. 2001. Local ecological knowledge and institutional dynamics for ecosystem management: a study of Lake Racken Watershed, Sweden. Ecosystems 4:85-104. http://dx. doi.org/10.1007/s100210000061

Olsson, P., C. Folke, and F. Berkes. 2004. Adaptive comanagement for building resilience in social-ecological systems. Environmental Management 34:75-90. http://dx.doi.org/10.1007/s00267-003-0101-7

Osawa, S., T. Katsuno, and Y. Hayama. 2001. Study on the leadership-training course of coppice management by public participation. Papers on Environmental Information Science 15:185-190.

Pickett, S. T. A., M. L. Cadenasso, J. M. Grove, C. G. Boone, P. M. Groffman, E. Irwin, S. S. Kaushal, V. Marshall, B. P. McGrath, C. H. Nilon, R. V Pouyat, K. Szlavecz, A. Troy, and P. Warren. 2011. Urban ecological systems: scientific foundations and a decade of progress. Journal of Environmental Management 92:331-362. http://dx.doi.org/10.1016/j.jenvman.2010.08.022

Pilgrim, S. E., L. C. Cullen, D. J. Smith, and J. Pretty. 2008. Policy analysis: ecological knowledge is lost in wealthier communities and countries. Environmental Science \& Technology 42:1004-1009. http://dx.doi.org/10.1021/es070837v

R Development Core Team 2010. R: A language and environment for statistical computing. R Foundation for Statistical Computing, Vienna, Austria. [online] URL: http://www.R-project.org

Rasbash, J., and H. Goldstein. 1994. Efficient analysis of mixed hierarchical and cross-classified random structures using a multilevel model. Journal of Educational and Behavioral Statistics 19:337-350. http://dx.doi.org/10.3102/10769986019004337

Reed, M. S., A. C. Evely, G. Cundill, I. Fazey, J. Glass, A. Laing, J. Newig, B. Parrish, C. Prell, C. Raymond, and L. C. Stringer. 2010. What is social learning? Ecology and Society 15(4): r1. [online] URL: http://www.ecologyandsociety.org/vol15/iss4/ resp1/

Sallu, S. M., C. Twyman, and L. C. Stringer. 2010. Resilient or vulnerable livelihoods? Assessing livelihood dynamics and trajectories in rural Botswana. Ecology and Society 15(4): 3. [online] URL: http://www.ecologyandsociety.org/vol15/iss4/art3/

Secretariat of the Convention on Biological Diversity 2012. Cities and biodiversity outlook-executive summary. Secretariat of the Convention on Biological Diversity, Montreal, Canada. [online] URL: http://www.cbd.int/en/subnational/partners-and-initiatives/ $\underline{\mathrm{cbo}}$

Takeuchi, K. 2003. Satoyama landscape as managed nature. Pages 9-16 in K. Takeuchi, R. D. Brown, I. Washitani, A. Tsunekawa, and M. Yokohari, editors. Satoyama: the traditional rural landscape of Japan. Springer-Tokyo, Tokyo, Japan.

Tatsui, M., and E. Fujii. 2006. Effect of satoyama preservation activity by civic group on vegetation and participants' awareness.
Journal of Japanese Institution of Landscape Architecture 69:777-780. http://dx.doi.org/10.5632/jila.69.777

Tsuchiya, K., T. Okuro, and K. Takeuchi. 2013. The combined effects of conservation policy and co-management alter the understory vegetation of urban woodlands: a case study in the Tama Hills area, Japan. Landscape and Urban Planning 110:87-98. http://dx.doi.org/10.1016/j.landurbplan.2012.10.013

Tsuchiya, K., and K. Takeuchi 2010. Satoyama conservation strategies of different municipalities in the urban fringe of the Tokyo metropolitan area. Journal of International City Planning 1:265-274.

Tsunekawa, A., and T. Bessho 2003. Satoyama landscape transition in the Kanto region. Pages 51-60 in K. Takeuchi, R. D. Brown, I. Washitani, A. Tsunekawa, and M. Yokohari, editors. Satoyama: the traditional rural landscape of Japan. SpringerTokyo, Tokyo, Japan.

United Nations (UN). 2011. World urbanization prospects: the 2011 revision. United Nations Population Division, New York, New York, USA. [online] URL: http://esa.un.org/unpd/wup/ index.htm

Yli-Pelkonen, V., and J. Kohl. 2005. The role of local ecological knowledge in sustainable urban planning: perspectives from Finland. Sustainability: Science, Practice \& Policy 1:3-14.

Yokohari, M., and J. Bolthouse. 2011a. Keep it alive, don't freeze it: a conceptual perspective on the conservation of continuously evolving satoyama landscapes. Landscape and Ecological Engineering 7:207-216. http://dx.doi.org/10.1007/s11355-010-0116-1

Yokohari, M., and J. Bolthouse. 2011b. Planning for the slow lane: the need to restore working greenspaces in maturing contexts. Landscape and Urban Planning 100:421-424. http://dx.doi. org/10.1016/j.landurbplan.2011.02.024

Yokohari, M., R. D. Brown, and K. Takeuchi. 1994. A framework for the conservation of rural ecological landscapes in the urban fringe area in Japan. Landscape and Urban Planning 29:103-116. http://dx.doi.org/10.1016/0169-2046(94)90021-3 
Appendix 1. Summary of questionnaire given to individual participants of community groups in satoyama woodland management.

\section{PROCEDURE}

The questionnaire consisted of five A4 printed pages. Researchers visited each individual group activity and asked each participant to fill out distributed questionnaires at the same time. Researchers asked the leaders of visited groups for their cooperation before the questionnaire session to ensure as many respondents as possible. Researchers explained the objectives of the questionnaire to respondents and gave instruction on how to mark their answers. Respondents were able to ask questions before and during providing answers if they were uncertain about any point in the questionnaire. Researchers replied to those questions as much as possible without disturbing the respondents' answering process. Researchers quickly checked incorrect marks when they received returned questionnaires but did not ask the respondents to correct them.

\section{QUESTIONS}

Questions were divided into four categories: knowledge about satoyama woodlands, experience in management activities, group participation personal history, and personal details. Each category contained several key questions as explained below.

\section{Knowledge about satoyama woodlands}

Respondents were asked "Do you know the following characteristics of satoyama woodland?" and answered "Yes, I know" or "No, I don't know" for the following eight points. Knowledge acquiring processes included reading a book, learning from others, and other formats. The eight characteristics were closely related to woodland management were selected based on the earlier literature on satoyama woodland management (e.g., Kameyama 1996, Takeuchi 2001). The list included both historical (e.g., Producing fuel and charcoal) and contemporary (e.g., Being used as educational spaces for nature and culture) characteristics. "Producing fuel and charcoal" and "Producing compost from collected fallen leaves" were core aspects of past coppice management in satoyama woodland (Takeuchi 2001) but may not be clearly recognized by urban residents. "Collecting edible mushrooms and plants" and "Planting and growing mushrooms on logged trees" were also important historically (Cetinkaya 2009) but urban residents usually do not depend on satoyama woodland for their food source. "Timber use of logged trees" was actually a minor part of historical management because the major 
function of satoyama woodland was to produce fuel and charcoals. "Creating habitats for animals and plants," "Providing public recreational spaces," and "Being used as educational spaces for nature and culture" are recognized more recently by urban residents as a value of satoyama woodland.

\section{Experience in management activities}

Respondents answered "Do you have experience in the following characteristics of satoyama woodland?" with "Yes, I have experience" or "No, I don't have experience" for the following 15 points. Experiences could have been at any time in their life and may have happened in the groups they had joined previously. The question list included both relatively easy (e.g., Cutting undergrowth with hand sickles) and difficult (e.g., Cutting trees with machines) skills to learn. This section was divided into three subcategories, "Physical activities in woodland management," "Tree/grass selection process before management activities," and "The use of woody products." "Physical activities in woodland management" included "Cutting undergrowth with hand sickles," "Cutting undergrowth with machines (e.g., brush cutter)," "Removing exotic species," "Cutting trees with hand saws," "Cutting trees with machines (e.g., chain saws)," "Pruning tree branches," "Managing shoots from the trunks of coppiced trees," and "Planting new trees and establishing seedlings." "Tree/grass selection process before management activities" was sometimes conducted before "Physical activities in woodland management" to select species or individual plants to be removed. Field observation showed that this process was often led by experts in groups in cooperation with other members. This subcategory included "Selecting grasses not to be cut (i.e., protected)," "Selecting exotic species to be removed," "Selecting trees not to be cut (i.e., protected)," and "Selecting branches to be retained during pruning and shoot management." "The use of woody products" included "Making fertilizers from collected fallen leaves," "Making charcoal from logged trees," and "Planting and growing mushrooms on logged trees."

\section{Group participation personal history}

This section included questions regarding years participating ("How many years have you participated in the activities of this group?"), participating in activities since group establishment (two categories: Yes or No), participation in other groups (two categories: have or have not), and motivation for joining (five categories: social interaction with other members, interest in the natural environment, interest in agricultural activities, contribution to the local community, and feeling refreshed in both body and mind). The 
five classes for motivation questions were defined based on the interview with group leaders and the review of literature (e.g., Kuramoto and Nagai 2002).

\section{Personal details}

This section included questions regarding age (three categories: under 50, 60, and 70), sex (two categories: male and female), and experience in professional forestry, agriculture, or landscaping (two categories: have and have not). 